\title{
Characteristics of promising strawberry varieties and elite forms by chemical composition and genes of the aromatic complex of fruits
}

\author{
Irina Luk'yanchuk, Ekaterina Zhbanova, and Alexander Lyzhin* \\ "I.V. Michurin Federal Scientific Center", 393774 Michurinsk, Russian Federation
}

\begin{abstract}
The results of the analysis of promising strawberry genotypes by the chemical composition and genes, involved in the determination of fruit aroma, are presented. By the complex of chemical traits, the strawberry varieties and elite forms of breeding of the I.V. Michurin Federal Scientific Center are highlighted: Flora (sugars $-9.2 \%$, ascorbic acid $-65.0 \mathrm{mg} / 100 \mathrm{~g}$, anthocyanins $-74.2 \mathrm{mg} / 100 \mathrm{~g}$ ), elite seedling $56-5$ (Gigantella Maxim $\times$ Privlekatelnaya) (sugars $-8.1 \%$, ascorbic acid -83.5 $\mathrm{mg} / 100 \mathrm{~g}$, anthocyanins $-64.3 \mathrm{mg} / 100 \mathrm{~g}$ ). These strawberry forms are also characterized by a homozygous state of the functional allele of the $\mathrm{FaOMT}$ gene of the aromatic complex of fruits, which indicates high mesifurane content in fruits. The research results can be used in further work on the creation of strawberry varieties with a high level of taste and aromatic qualities, and also the antioxidant value of the fruits.
\end{abstract}

\section{Introduction}

Strawberry (Fragaria $\times$ ananassa Duch.) is one of the most popular and widely cultivated berry crops in the world. Modern strawberry breeding programs are focused on the creation of new varieties with increased resistance to pests and diseases, and high nutritional and taste-aromatic qualities of fruits [1].

Many Russian and foreign researchers [2-5] note a high antioxidant potential and therapeutic and prophylactic properties of strawberry fruits, associated with the accumulation of sugars, dietary fiber, minerals and vitamins (ascorbic acid, folic acid and polyphenols).

Volatile organic compounds found in strawberry fruits include esters, terpenes, aldehydes, ketones, alcohols and etc. Among them, only a few compounds contribute to the creation of the unique strawberry fruit aroma, and their biosynthesis and accumulation depend on the genotype and the environment [3]. Among the key aromatic volatiles of strawberry fruits are $\gamma$-decalactone (5-hexyloxolan-2-one) and mesifurane (2,5-dimethyl-4methoxy-2,3-dihydro-3-furanone). Biosynthesis of mesifurane is controlled by the FaOMT gene [6]. Biosynthesis of $\gamma$-decalactone is controlled by the FaFAD1 gene [7].

${ }^{*}$ Corresponding author: Ranenburzhetc@yandex.ru 
The purpose of this study was to assess promising strawberry varieties and elite forms by the most important components of the chemical composition and genes of the aromatic complex of fruits and identified valuable genotypes by a complex of traits.

\section{Materials and methods}

The studies were carried out in 2015-2020. Biological material was represented by promising foreign strawberry varieties and strawberry varieties and elite forms, created in "I.V. Michurin Federal Scientific Center".

The content of the components of the chemical composition of fruits was determined by standard methods: the soluble solids content was determined by refractometric, the sugars content - by Bertrand method, the organic acids content - by titration with $0.1 \mathrm{~N} \mathrm{NaOH}$ in terms of citric acid, the ascorbic acid content - by iodometric method, the anthocyanins content - by $\mathrm{pH}$ differential spectrophotometry $[8,9]$. Statistical analysis of the obtained results was carried out using the package of mathematical statistics Microsoft Excel 2016.

The genes of the aromatic complex of fruits were identified using diagnostic DNA markers. Extraction of total strawberry DNA was carried out according to the DArT protocol with additions [10]. The FaFADl gene controlled the $\gamma$-decalactone content in fruits was identified with the dominant marker FaFAD1 [7]. The allelic state of the FaOMT gene controlled the mesifurane content in fruits was identified with the codominant marker FaOMT-SI/NO [6]. The polymerase chain reaction was carried out in a T100 thermal cycler (Bio-Rad) in the modes described earlier [11]. Amplification products were separated by electrophoretic method in agarose gel.

\section{Results and discussion}

According to the obtained data (Table 1), the strawberry varieties Lastochka and Flora (breeding of "I.V. Michurin Federal Scientific Center") are characterized by high level of the chemical composition of fruits, exceeding the control (variety Elianny) in terms of the content of soluble solids and sugars. The high content of soluble solids and sugars was also characteristic of the strawberry elite seedlings 35-5 (922-67 $\times$ Maryshka) and 56-51 (Gigantella Maxim $\times$ Privlekatelnaya). All analyzed strawberry varieties and elite forms have moderate acidity of fruits, corresponding to the values recommended for strawberry (no more than $1.5 \%$ ).

Table 1. The chemical composition of promising strawberry varieties and elite forms.

\begin{tabular}{|c|c|c|c|c|}
\hline Genotype & Originator & $\begin{array}{c}\text { Soluble solids, } \\
\% \text { Brix }\end{array}$ & Sugars, $\%$ & $\begin{array}{r}\text { Titratable } \\
\text { acidity, \% } \\
\end{array}$ \\
\hline Lastochka & \multirow{2}{*}{$\begin{array}{l}\text { "I.V. Michurin Federal } \\
\text { Scientific Center", Russia }\end{array}$} & 11,6 & 8,9 & 0,63 \\
\hline Flora & & 12,6 & 9,2 & 1,04 \\
\hline Arosa & $\begin{array}{l}\text { Consorzio Italiano } \\
\text { Vivaisti, Italy }\end{array}$ & 11,5 & 6,3 & 1,05 \\
\hline Asia & New Fruits, Италия & 9,2 & 5,7 & 0,94 \\
\hline Clery & $\begin{array}{c}\text { Consorzio Italiano } \\
\text { Vivaisti, Italy }\end{array}$ & 8,9 & 6,5 & 0,80 \\
\hline Elianny (к) & $\begin{array}{l}\text { Gebr. Vissers, } \\
\text { Netherlands }\end{array}$ & 9,1 & 6,7 & 0,68 \\
\hline Selva & $\begin{array}{c}\text { University of California } \\
\text { Davis, USA }\end{array}$ & 8,3 & 5,3 & 0,78 \\
\hline $35-5$ & \multirow{2}{*}{$\begin{array}{l}\text { "I.V. Michurin Federal } \\
\text { Scientific Center", Russia }\end{array}$} & 11,1 & 8,1 & 0,84 \\
\hline $56-5$ & & 10,8 & 8,1 & 1,04 \\
\hline
\end{tabular}




\begin{tabular}{|l|c|c|c|}
\hline $56-51$ & 11,6 & 8,3 & 1,25 \\
\cline { 3 - 4 } & 9,2 & 6,9 & 0,84 \\
\hline Mean $(\mathrm{x})$ & 10,4 & 7,3 & 0,90 \\
\hline Standard errors $\left(\mathrm{S}_{(\mathrm{x})}\right)$ & 0,43 & 0,39 & 0,06 \\
\hline Limits of variation (min.-max.) & $8,3-12,6$ & $5,3-9,2$ & $0,63-1,25$ \\
\hline
\end{tabular}

Strawberry fruits are of particular value as a source of ascorbic acid (vitamin C). The highest ascorbic acid content $(80.0 \mathrm{mg} / 100 \mathrm{~g}$ or more) was characteristic of the strawberry elite seedlings 56-5 and 56-51 (Gigantella Maxim $\times$ Privlekatelnaya) (Figure 1).

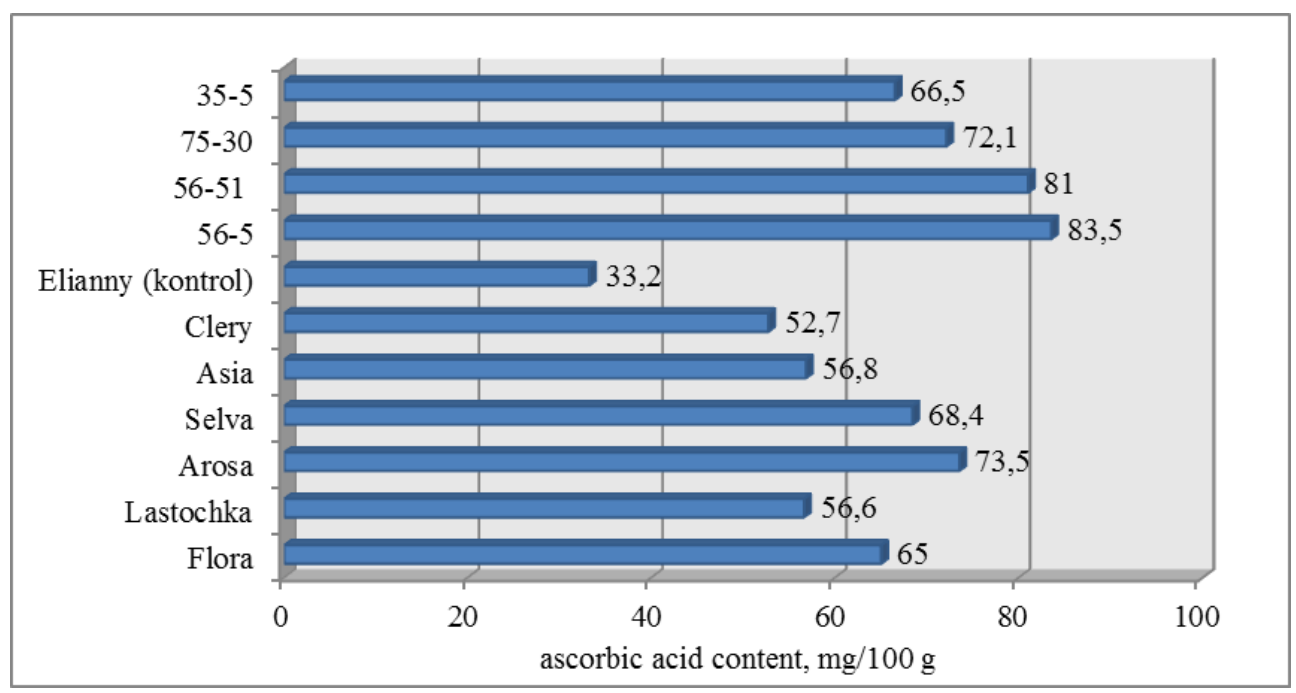

Fig. 1. The ascorbic acid content in the fruits of promising strawberry varieties and elite forms.

Fruits of the strawberry variety Arosa and elite seedling 75-30 (Tokado $\times$ Elianny) accumulated above $70.0 \mathrm{mg} / 100 \mathrm{~g}$ of ascorbic acid. Strawberry varieties Lastochka and Flora exceeded the control (variety Elianny) in ascorbic acid content by $70.5 \%$ and $95.8 \%$, respectively.

Anthocyanins are the most important polyphenolic compounds of strawberry fruits, determining not only the attractive color of the fruit, but also their antioxidant properties, and their suitability for fruit processing. The smallest anthocyanins content was characteristic of the strawberry variety Arosa $(24.2 \mathrm{mg} / 100 \mathrm{~g})$. The highest anthocyanins content was characteristic of the strawberry variety Flora (74.2 mg/100 g) (Figure 2). 


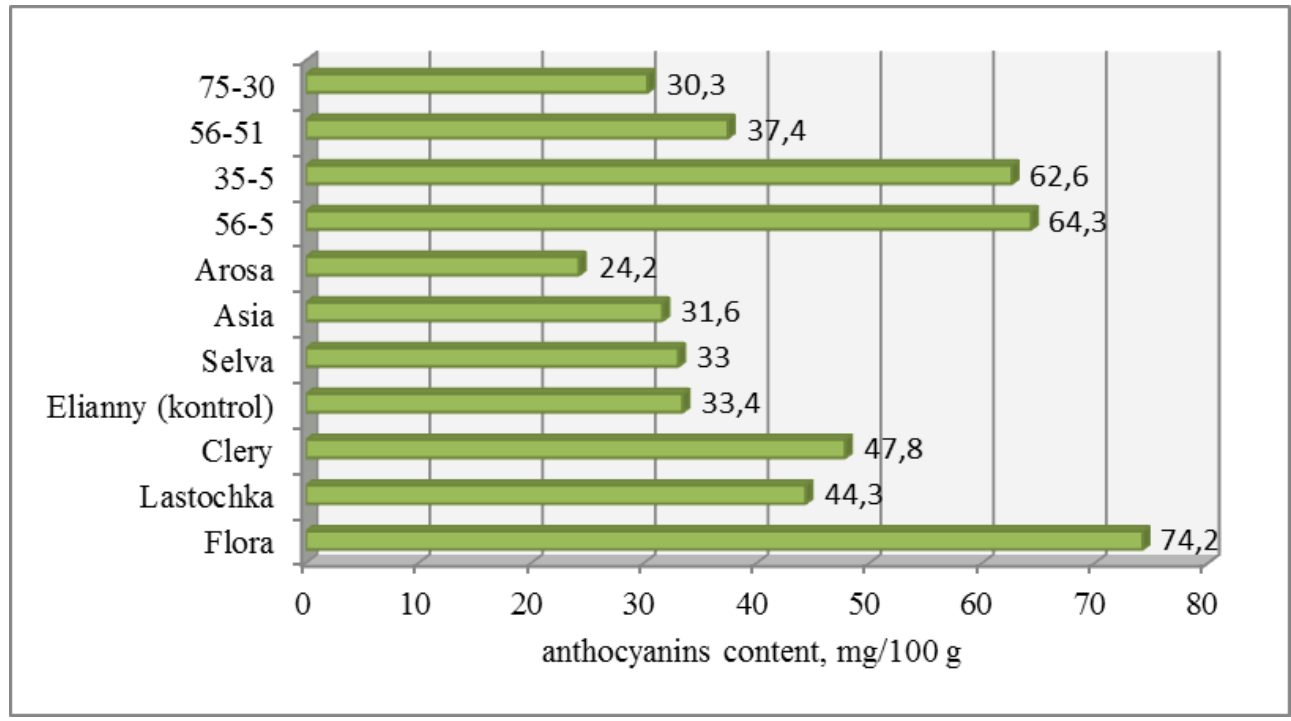

Fig. 2. The anthocyanins content in the fruits of promising strawberry varieties and elite forms.

Fruits of the strawberry variety Flora, and elite seedlings 56-5 (Gigantella Maxim $\times$ Privlekatelnaya) and 35-5 (922-67 × Maryshka) accumulated above $60.0 \mathrm{mg} / 100 \mathrm{~g}$ of anthocyanins. Strawberry varieties Lastochka, Flora and Clery, and elite seedlings 56-5, 5651 (Gigantella Maxim $\times$ Privlekatelnaya) and 35-5 (922-67 $\times$ Maryshka) exceeded the control (variety Elianny) in terms of this trait.

Molecular genetic analysis of strawberry varieties and forms by genes of the aromatic complex of fruits showed that the $248 \mathrm{bp}$ fragment of the FaOMT-SI/NO marker, corresponding to the functional allele of the $\mathrm{FaOMT}$ gene, is present in strawberry varieties Arosa and Elianny (foreign breeding), Lastochka and Flora (breeding of "I.V. Michurin Federal Scientific Center"), and promising strawberry elite forms 56-5 and 56-51 (Gigantella Maxim $\times$ Privlekatelnaya) (Table 2).

Table 2. Allelic polymorphism of $F a O M T$ and $F a F A D 1$ fruit flavor volatiles genes in promising strawberry varieties and elite form ( 1 - allele is presence, 0 - allele is absence)

\begin{tabular}{|c|c|c|c|}
\hline \multirow{2}{*}{ Genotype } & \multicolumn{2}{|c|}{ Marker FaOMT-SI/NO } & Marker FaFAD1 \\
\cline { 2 - 4 } & $217 \mathrm{bp}$ & $248 \mathrm{bp}$ & $500 \mathrm{bp}$ \\
\hline Lastochka & 0 & 1 & 0 \\
\hline Flora & 0 & 1 & 0 \\
\hline Arosa & 0 & 1 & 1 \\
\hline Asia & 1 & 0 & 0 \\
\hline Clery & 1 & 0 & 0 \\
\hline Selva & 1 & 0 & 0 \\
\hline Elianny & 0 & 1 & 0 \\
\hline $56-5$ & 0 & 1 & 0 \\
\hline $56-51$ & 1 & 1 & 0 \\
\hline
\end{tabular}

The strawberry varieties Arosa, Elianny, Lastochka and Flora, and the elite form 56-5 are characterized by a homozygous state of the functional allele of the FaOMT gene, which, according to Zorrilla-Fontanesi et al. [6] and Cruz-Rus et al. [12] corresponds to the maximum level of mesifurane content in fruits. In the strawberry varieties Asia, Clery and Selva, the FaOMT-SI/NO marker is represented by the 217 bp amplicon, which corresponds to the homozygous state of the non-functional allele of the FaOMT gene. 
The FaFAD1 gene among the studied strawberry genotypes was identified only in the variety Arosa. Strawberry varieties Lastochka, Flora, Asia, Clery, Selva and Elianny, and elite forms 56-5 and 56-51 are characterized by the absence of the FaFAD1 gene. It should be noted that the strawberry elite forms $56-5$ and 56-51 were identified in the crossing combination Gigantella Maxim $\times$ Privlekatelnaya, in which, according to previous studies [11], the variety Gigantella Maxim is characterized by the presence of the FaFAD1 gene. Therefore, the probability of obtaining strawberry genotypes with the FaFADl gene in this combination is $50 \%$.

\section{Conclusion}

Thus, the results of the studies show, that varieties and promising elite seedlings of strawberry, created in the "I.V. Michurin Federal Scientific Center" are characterized by high levels of chemical composition, not inferior (and in some cases superior) to modern foreign strawberry varieties. According to the complex of chemical traits of fruits, strawberry variety Flora (sugars $-9.2 \%$, ascorbic acid $-65.0 \mathrm{mg} / 100 \mathrm{~g}$, anthocyanins $74.2 \mathrm{mg} / 100 \mathrm{~g}$ ) and strawberry elite form 56-5 (Gigantella Maxim $\times$ Privlekatelnaya) (sugars $-8.1 \%$, ascorbic acid $-83.5 \mathrm{mg} / 100 \mathrm{~g}$, anthocyanins $-64.3 \mathrm{mg} / 100 \mathrm{~g}$ ) were identified. These genotypes are also characterized by the homozygous state of the functional allele of the FaOMT gene of the aromatic complex of fruits. The obtained results can be used in breeding to create strawberry varieties with more attractive fruits in terms of sensory perception of taste, aroma and antioxidant value.

\section{References}

1. B. Mezzetti, F. Giampieri, Y. Zhang, C. Zhong, Journal of Berry Research 8(3), 205-221 (2018) https://doi.org/10.3233/jbr-180314

2. F. Giampieri, S. Tulipani, J.M. Alvarez-Suarez, J.L. Quiles, B. Mezzetti, M. Battino, Nutrition, 28 (1), 9-19 (2012) https://doi.org/10.1016/j.nut.2011.08.009

3. K. Zeliou, V. Papasotiropoulos, Y. Manoussopoulos, F.N. Lamari, Journal of the Science of Food and Agriculture 98(11), 4065-4073 (2018) https://doi.org/10.1002/jsfa.8923

4. M.Yu. Akimov, I.V. Luk'yanchuk, E.V. Zhbanova, A.S. Lyzhin, Chemistry of plant raw materials, 1, 5-18 (2020) https://doi.org/10.14258/jcprm.2020015511

5. T. Dzhanfezova, G. Barba-Espín, R. Müller, B. Joernsgaard, J.N. Hegelund, B. Madsen, T.B. $\begin{array}{lllll}\text { Toldam-Andersen, } & \text { Food } & \text { Bioscience, } & \mathbf{3 6} & 100620\end{array}$ https://doi.org/10.1016/j.fbio.2020.100620

6. Y. Zorrilla-Fontanesi, J.L. Rambla, A. Cabeza, J.J. Medina, J.F. Sánchez-Sevilla, V. Valpuesta, M.A. Botella, A. Granell, I. Amaya, Plant physiol., 159 (2), 851-870 (2012) https://doi.org/10.1104/pp.111.188318

7. A.H. Chambers, J. Pillet, A. Plotto, J. Bai, V.M. Whitaker, K.M. Folta, BMC genomics, 15 (1), 217 (2014) https://doi.org/10.1186/1471-2164-15-217

8. A.I. Ermakov, V.V. Arasimovich, N.P. Yarosh, Yu.V. Peruvian, G.A. Lukovnikov, M.I. Ikonnikova, Methods of biochemical research of plants, 430 (1987)

9. Manual on methods of quality control and safety of biologically active additives in food, 240 (2004)

10. I.V. Luk'yanchuk, A.S. Lyzhin, I.I. Kozlova, Vavilov Journal of Genetics and Breeding, 22 (7), 795-799 (2018) https://doi.org/10.18699/VJ18.423

11. A.S. Lyzhin, I.V. Luk'yanchuk, E.V. Zhbanova, Vavilov Journal of Genetics and Breeding, 24 (1), 5-11 (2020) https://doi.org/10.18699/VJ20.588 
12. E. Cruz-Rus, R. Sesmero, J.A. Ángel-Pérez, J.F. Sánchez-Sevilla, D. Ulrich, I. Amaya, Molecular breeding, 37 (10), 131 (2017) https://doi.org/10.1007/s11032-017-0732-7 